\title{
EARLY DEVELOPMENT OF CASTOR BEANS GROWN UNDER SALINITY CONDITIONS (VARIETIES BRS ENERGIA, MPA 34 AND MPB 01) ${ }^{1}$
}

\author{
RAFAEL ANTÔNIO PRESOTTO², GHILHERME ZOLLI ALVES ${ }^{2}$, ELISAMARA CALDEIRA DO NASCIMENTO², \\ GLAUCIO DA CRUZ GENUNCIO ${ }^{2 *}$, EVERALDO ZONTA ${ }^{2}$
}

\begin{abstract}
Studies have shown that some plant species exhibit satisfactory production levels when grown under high salinity levels, whereas others exhibit decreased production due to sodium sensitivity even at low sodium concentrations. The castor bean is moderately sensitive to salinity. The aim of the present study was to evaluate the early growth of three castor bean varieties (BRS Energia, MPA 34 and MPB 01) grown in nutrient solution with increasing sodium concentrations (control, 25, 50, 75 and $100 \mathrm{mmol} \mathrm{L}^{-1}$ ). A completely randomized split-plot experimental design was used, with a $5 \times 3$ factorial scheme and three replicates per treatment. Salinity resulted in decreased dry weight of all castor bean varieties grown for 31 days under hydroponic conditions. The dry weight accumulation was less affected at the root than at the shoot level. Nevertheless, the shoot dry weight decreased with the increasing salinity. MPA 34 exhibited higher early growth than the remaining tested varieties. Salinity affected the early development of the tested castor bean varieties, and this effect was more pronounced at the shoot than at the root. Variety MPA 34 is promising for cultivation under moderate salinity levels.
\end{abstract}

Keywords: Ricinus communis. Sodium sensitivity. Osmotic adjustment.

\section{DESENVOLVIMENTO INICIAL DA MAMONEIRA EM CONDIÇÕES SALINAS (VARIEDADES BRS ENERGIA, MPA 34 e MPB 01)}

\begin{abstract}
RESUMO - Pesquisas demonstram produções satisfatórias de espécies quando cultivadas em altos níveis de salinidade, enquanto outras reduzem a sua produção por apresentarem sensibilidade ao sódio, mesmo em baixas concentrações. A mamoneira é moderadamente sensível à salinidade e, neste sentido, este trabalho teve por objetivo avaliar o crescimento inicial de três cultivares de mamoneira (BRS Energia, MPA34 e MPB 01), cultivadas em solução nutritiva, com concentrações crescentes de sódio (controle; 25; 50; 75 e 100 mmol L-1). O delineamento experimental foi inteiramente casualizado, em fatorial $5 \times 3$ e parcela subdividida, com três repetições. A salinidade reduziu a matéria seca de todas as variedades de mamoneira cultivadas por 31 dias em sistema hidropônico. Entretanto, observou-se que o sistema radicular foi menos afetado quanto ao acúmulo de matéria seca, quando comparado ao acúmulo da parte aérea. Ainda assim, a matéria seca da parte aérea reduziu gradativamente a partir do aumento da salinidade. A variedade MPA 34 apresentou maior crescimento inicial, quando comparada as demais variedades. A salinidade afetou o desenvolvimento inicial das variedades de mamoneira, sendo a parte aérea mais afetada que o sistema radicular. O cultivo da variedade MPA 34 demonstrou-se promissor sob condições de moderados níveis de salinidade.
\end{abstract}

Palavras-chave: Ricinus communis. Sensibilidade ao sódio. Ajustamento osmótico.

\footnotetext{
*Corresponding author

${ }^{1}$ Received for publication in 08/11/2014; accepted in 07/01/2016.

Paper extracted from the master thesis of the first author.

${ }^{2}$ Department of Soil, Universidade Federal Rural do Rio de Janeiro, Seropédica, RJ, Brazil; presotto_ufrrj@hotmail.com, guilhermezolli@hotmail.com, elisamara.caldeira@gmail.com,glauciogenuncio@gmail.com, ezonta@ufrrj.br.
} 


\section{INTRODUCTION}

Drought and the occurrence of saline and sodic soils have been forcing farmers to use water with increasingly higher salt concentrations for irrigation (SAVVAS et al., 2007). The use of brackish water and mineral fertilizers can also increase salinization, eventually causing arable soils to become unviable. Excess sodium is an important factor of salinity because it affects the physical and chemical properties of the soil by increasing the thickness of the diffuse double layer and consequently causing clay expansion and reduced soil porosity and permeability (KORNDÖRFER, 2006).

Different crop species display different levels of salinity tolerance that vary from sensitive to tolerant, with their growth and development affected to different extents (MAAS; HOFFMMAN, 1977). Waters are classified as brackish when they present salinity between 0.05 and $3.0 \%$ and as saline when the salinity is higher than $3.0 \%$ (CONAMA, 1986). Plants can have different tolerance or avoidance mechanisms or a combination of both. Constitutive resistance mechanisms are expressed independent of the plant's stress state and constitute evolutionary adaptations that improve the adaptation of populations to environmental factors. In turn, resistance mechanisms leading to the adaptation of individual organisms to variations in environmental factors are called acclimatization (BRAY; BAILEY-SERRES; WERETILNYK, 2000).

Studies have shown that some groups of crops exhibit satisfactory production levels under high salinity conditions, whereas other crops are more sensitive to the same salinity conditions (CARUSO; VILLARI, 2004; AL-KARAKI; AL-AJMI; OTHMAN, 2009; RUBIO et al., 2009). Plant tolerance to saline stress may depend on the regulation of sodium uptake and allocation (CHEESEMAN, 1988).

The castor bean is considered moderately sensitive to salinity due to its resistance to drought and high seed germination. However, salinity can affect the early growth of castor bean seedlings and consequently compromise their establishment. Salinity affects plants by decreasing the plant's water potential, resulting in decreased gas exchange and shoot dry weight accumulation. However, because the castor bean is considered adaptable to salinity, it is widely grown in most soils in northeast Brazil (AYERS; WESTCOT, 1999; PINHEIRO et al., 2008; SILVA et al., 2008a; SANTOS et. al., 2013).

The aim of the present study was to compare the early growth of three castor bean commercial varieties grown in nutrient solutions containing increasing sodium concentrations $(25,50,75$ and $100 \mathrm{mmol} \mathrm{L}^{-1}$ ).

\section{MATERIAL AND METHODS}

The experiment was performed in a greenhouse at the Soil Department of the Federal Rural University of Rio de Janeiro (Universidade Federal Rural do Rio de Janeiro), located in Seropédica, state of Rio de Janeiro (RJ) $\left(22^{\circ} 45^{\prime} \mathrm{S}\right.$, $\left.43^{\circ} 41^{\prime} \mathrm{W}\right)$. Castor bean seeds were sown in a sandy substrate. The seedlings were transferred 16 days after sowing (DAS) to $36 \mathrm{~L}$ plastic boxes containing half-strength Hoagland and Arnon (1950) nutrient solution under constant aeration. The plants were left to acclimatize to the hydroponic conditions for four days. Then, the nutrient solution was replaced with nutrient solutions containing different $\mathrm{NaCl}$ concentrations. The plants remained under these conditions for 10 days and were analyzed 31 DAS.

A split-plot completely randomized experimental design was used, with a $5 \times 3$ factorial scheme and three replicates per treatment. The levels of the first factor were the five sodium concentrations in the nutrient solution (control, 25, 50,75 and $100 \mathrm{mmol} \mathrm{L}^{-1}$ ). The levels of the second factor were the three different castor bean varieties (BRS Energia, MPA 34 and MPB 01). Each subplot contained three plants of each variety for a total of nine plants in each main plot.

The $\mathrm{pH}$, electrical conductivity (EC), nutrient solution temperature, relative air humidity ( $\mathrm{RH} \%)$, and greenhouse temperature were monitored daily at 9:00 A.M. and 3:00 P.M. during the 14 days of hydroponic cultivation. The $\mathrm{pH}$ of the nutrient solution was adjusted to 6 with $0.1 \mathrm{~N} \mathrm{KOH}$ and 0.1 $\mathrm{N} \mathrm{H}_{2} \mathrm{SO}_{4}$. During the experiment, the mean air temperature was $27 \pm 2^{\circ} \mathrm{C}$, the mean $\mathrm{RH} \%$ was $75 \pm 5 \%$, and the mean temperature of the nutrient solution was $25 \pm 1{ }^{\circ} \mathrm{C}$. The different treatments exhibited different mean nutrient solution ECs for the 10 days of treatment, with $1.2,4.6,6.7,9.3$, and $11.4 \mathrm{dS} \mathrm{m}^{-1}$ observed for the control and the 25,50 , 75 and $100 \mathrm{mmol} \mathrm{L}^{-1} \mathrm{Na}$ concentrations, respectively.

All plants were harvested 10 days after the treatment application (31 DAS). The stem diameter and plant height were measured. The plants were immediately separated into roots and shoots, weighed and dried in a forced-air oven at $65^{\circ} \mathrm{C}$ to a constant weight. The percentage root dry weight $(\%$ RDW; \%RDW=RFW/RDW*100) and percentage shoot dry weight $(\% \mathrm{SDW} ; \% \mathrm{SDW}=\mathrm{SFW} / \mathrm{SDW} * 100)$ were calculated using the ratio between the dry (DW) and fresh weights (FW). This estimate allowed us to infer the plant tissue succulence, which is usually affected by saline stress (KLUGE; ETING, 1978).

The data were tested for normality (Lilliefors test) and homogeneity of variance (Bartlett and Cochran tests). When the data did not meet the normality and homogeneity of variance assumptions, they were $\ln (\mathrm{x}+1)$ transformed. When the factors 
were found to have significant effects according to the $t$ test at $p<0.05$, the quantitative factor (salinity) was analyzed separately using linear regression, and the regression coefficients were tested using the $t$ test at $\mathrm{p}<0.05$. All statistical analyses were performed using SAS 9.0 (SAS INSTITUTE INC, 2002).

\section{RESULTS AND DISCUSSION}

The analysis of variance of the data obtained for the different castor bean varieties grown in nutrient solutions with different salinity levels revealed that salinity had a significant effect on most of the quantified parameters (Table 1). Only the percent shoot dry weight $(\% \mathrm{SDW})$ was not affected by salinity. Significant differences in the stem diameter (SD), plant height, root fresh weight (RFW), shoot fresh weight (SFW) and shoot dry weight (SDW) were observed between the different varieties. No significant differences in root dry weight (RDW), percent shoot dry weight (\%SDW), $\%$ RDW, and RFW/SFW were observed between the different varieties grown with the different salinity levels (Table 1).

Table 1. Mean square and coefficient of variation for the analysis of variance of the measured phenological parameters.

\begin{tabular}{ccccccccccc}
\hline VF & SD & Height & RFW & SFW & RFW/SFW & RDW & SDW & RDW/SDW & $\% R D W$ & $\%$ SDW \\
\hline Salinity & $18.5^{* *}$ & $88.7^{* *}$ & $76.3^{*}$ & $1104^{* *}$ & $0.49^{* *}$ & $0.21^{*}$ & $13.0^{* *}$ & $0.03^{* *}$ & $0.08^{* *}$ & $0.48^{\text {ns }}$ \\
Variety & $5.38^{*}$ & $248^{* *}$ & $177^{* *}$ & $180^{* *}$ & $0.01^{\text {ns }}$ & $0.03^{\text {ns }}$ & $3.03^{*}$ & $0.01^{* *}$ & $0.00^{\mathrm{ns}}$ & $2.67^{\mathrm{ns}}$ \\
$\mathrm{S}^{*} \mathrm{~V}$ & $0.64^{\mathrm{ns}}$ & $9.59^{* *}$ & $16.3^{\mathrm{ns}}$ & $13.7^{\mathrm{ns}}$ & $0.01^{\mathrm{ns}}$ & $0.07^{\mathrm{ns}}$ & $0.22^{\mathrm{ns}}$ & $0.00^{\mathrm{ns}}$ & $0.00^{\mathrm{ns}}$ & $0.38^{\mathrm{ns}}$ \\
\hline $\mathrm{CV} 1(\%)$ & 13.0 & 10.4 & 17.8 & 16.4 & 9.6 & 18.1 & 12.2 & 12.1 & 2.7 & 12.6 \\
$\mathrm{CV} 2(\%)$ & 13.9 & 7.8 & 18.0 & 17.3 & 7.7 & 20.0 & 17.5 & 13.1 & 2.3 & 8.3 \\
\hline
\end{tabular}

${ }^{*},{ }^{* *}$ Significant according to the $\mathrm{t}$ test at $\mathrm{p}<0.05$ and $\mathrm{p}<0.01$, respectively; ${ }^{\text {ns }}$ : non-significant. ${ }^{\mathrm{Ln}}$ : Data were $\operatorname{Ln}(\mathrm{x}+1)$ transformed. CV1: coefficient of variation for the salinity factor. CV2: coefficient of variation for the variety factor.

Salinity was previously observed to result in a lower number of leaves, stem diameter, plant height and shoot fresh weight in castor bean plants; in contrast, salinity did not affect the percent dry weight or germination time (Cavalcanti et al., 2005).

A significant interaction between the salinity level and castor bean variety was only observed for plant height, indicating that the response to salinity of at least one castor bean variety was significantly different from the responses of the remaining tested varieties. The effect of salinity on plant height was less pronounced for MPB 01 than for the remaining tested varieties (Figure 1). However, MPB 01 exhibited a lower height than the remaining varieties. The highest sodium concentration tested

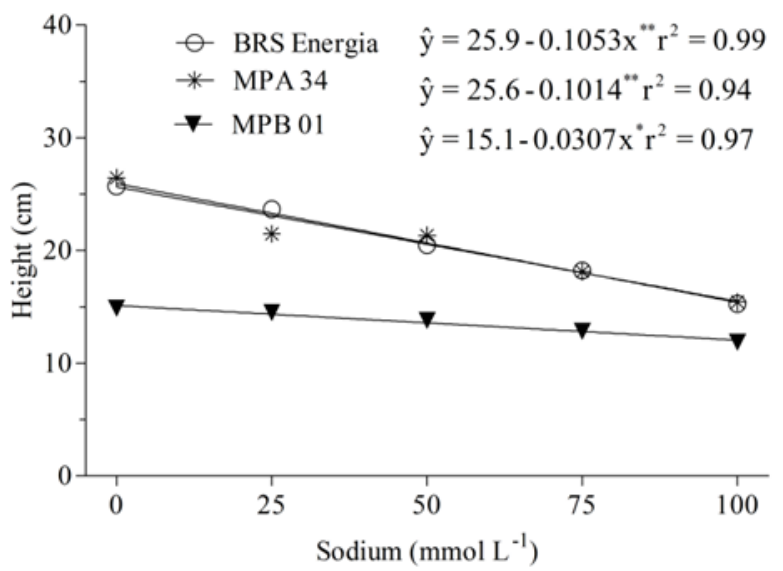

(100 mmol $\mathrm{L}^{-1}$ ) resulted in a $41 \%$ decrease in plant height for BRS Energia and a $42 \%$ decrease for MPA 34 compared to plants grown in nutrient solution without sodium (control), whereas the decrease was only $20 \%$ for MPB 01 .

The effects of salinity on the stem diameter also differed between different varieties, with MPB 01 presenting the lowest stem diameter. Excess $\mathrm{NaCl}$ in soils inhibits plant growth and production because the excess salts decrease the osmotic potential of the soil solution (SILVA et al., 2000). Silva et al. (2000) observed decreased stem diameters and dry weights in mastic trees due to the addition of $\mathrm{NaCl}$ to the substrate.

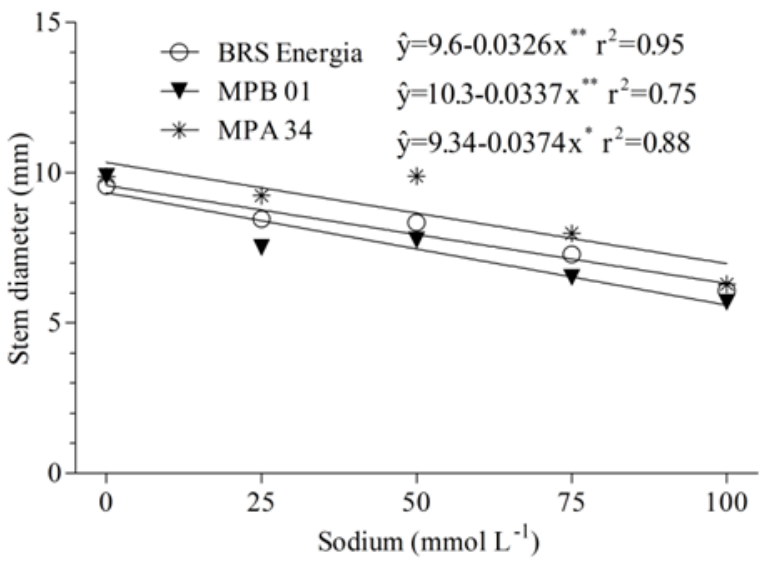

Figure 1. Plant height and stem diameter of different castor bean varieties grown in nutrient solutions with different salinity levels. ${ }^{*},{ }^{* *}$ : Coefficient significant at $\mathrm{p}<0.05$ or 0.01 , respectively. 
Regarding the effect of salinity on the fresh weight accumulation, the different sodium concentrations tested had no significant effect on the RFW for MPA 34 but resulted in significantly lower RFWs in BRS Energia and MPB 01. The highest sodium concentration tested resulted in a $33 \%$ decrease in the RFW for variety BRS Energia and a $37 \%$ decrease for MPB 01 relative to the control (Figure 2). The SFW was significantly decreased with the increasing salinity in all tested varieties. The angular coefficients of the regression equations indicated that the SFW decreased at similar rates for the three varieties. However, MPA 34 exhibited a higher SFW than the remaining tested varieties (Figure 2).

The ratio between the root and shoot fresh weights allows the evaluation of the physiological growth indices and the determination of which plant part is most affected by salinity. No differences in the RFW/SFW were observed between the different varieties, but the RFW/SFW increased significantly with increasing sodium concentrations in the nutrient solution. This relative decrease in the SFW indicates that the castor bean shoots were more affected by salinity than the roots. Although the roots were also affected by saline stress, they exhibited lower weight decreases than the shoots (Figure 2). Cavalcanti et al. (2005) also observed more pronounced effects of salinity on castor bean shoots than on the roots. However, significantly lower root and shoot growth under saline stress was observed in rocket grown under hydroponic conditions under laminar flow (SILVA et al., 2008b) and in melons (ARAGÃO et al., 2009), tomatoes (COSME et al., 2011) and chili peppers (NUNES et al., 2013) grown under semi-hydroponic conditions (coconut fiber).

JÚNIOR et al. (2013) evaluated the effect of salinity on the early growth of herbaceous cotton. The authors subjected seeds of cotton variety BRS-8H to five different sodium chloride concentrations $\left(0,1.6,3.2,4.8\right.$ and $\left.6.4 \mathrm{~g} \mathrm{~L}^{-1}\right)$ and observed significant decreases in the emergence speed index, germination percentage, seedling height, and shoot and root dry weights.
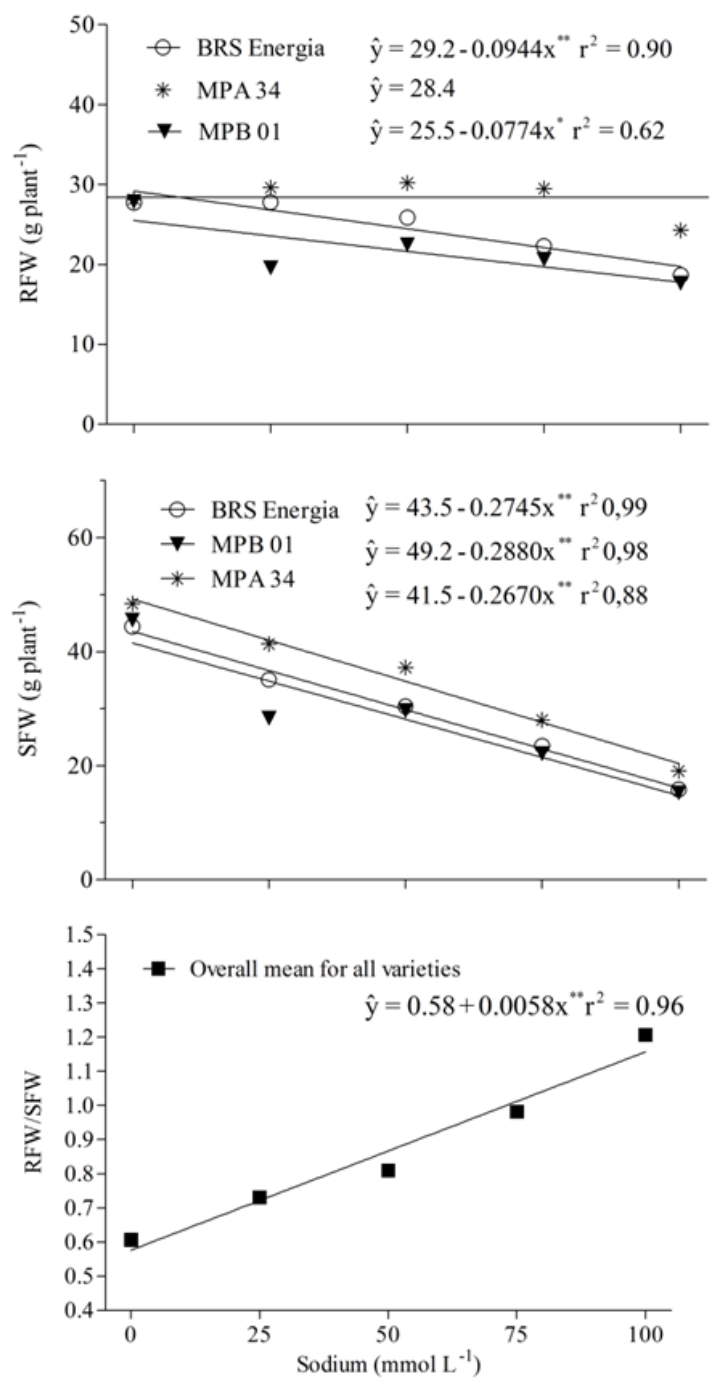

Figure 2. Root fresh weight (RFW), shoot fresh weight (SFW) and ratio between the RFW and SFW for different castor bean varieties grown in nutrient solution with different salinity levels. ${ }^{*}{ }^{* *}$ : Coefficient significant at $\mathrm{p}<0.05$ or 0.01 , respectively. 
Regarding the effect of salinity on dry weight accumulation, the RDW decreased with the increasing sodium concentrations for all varieties tested. However, no significant differences were observed between the different varieties. Notably, the $100 \mathrm{mmol} \mathrm{L}^{-1}$ sodium concentration caused a mean $24 \%$ decrease in the RDW compared to the control (Figure 3). The SDW significantly decreased with the increasing salinity for all varieties tested, following the same trend observed for the SFW. With $100 \mathrm{mmol} \mathrm{L}^{-1}$ sodium, the SDW decreased $53 \%, 60 \%$ and $49 \%$ relative to the control for BRS Energia, MPB 01, and MPA 34, respectively (Figure 3).

Significant differences in the RDW/SDW were observed among the different varieties. BRS
Energia presented an increasing RDW/SDW with increasing sodium concentrations in the nutrient solution (Figure 3). Similar results were previously observed for castor bean variety BRS 149 grown in soil irrigated with water with different salinity levels and $\mathrm{Na}$ : Ca ratios (Cavalcanti et al., 2005; Santos et al., 2013). Therefore, the increase in the RDW/SDW can be concluded to result from the moderate tolerance degree of castor beans to saline soils. An important physiological response to saline and sodic environments in terms of plant growth is the energy allocation towards root growth to increase the water and nutrient uptake (MARSCHNER, 1997). Therefore, the RDW/SDW ratio should be used as a complementary parameter for the evaluation of salinity tolerance.

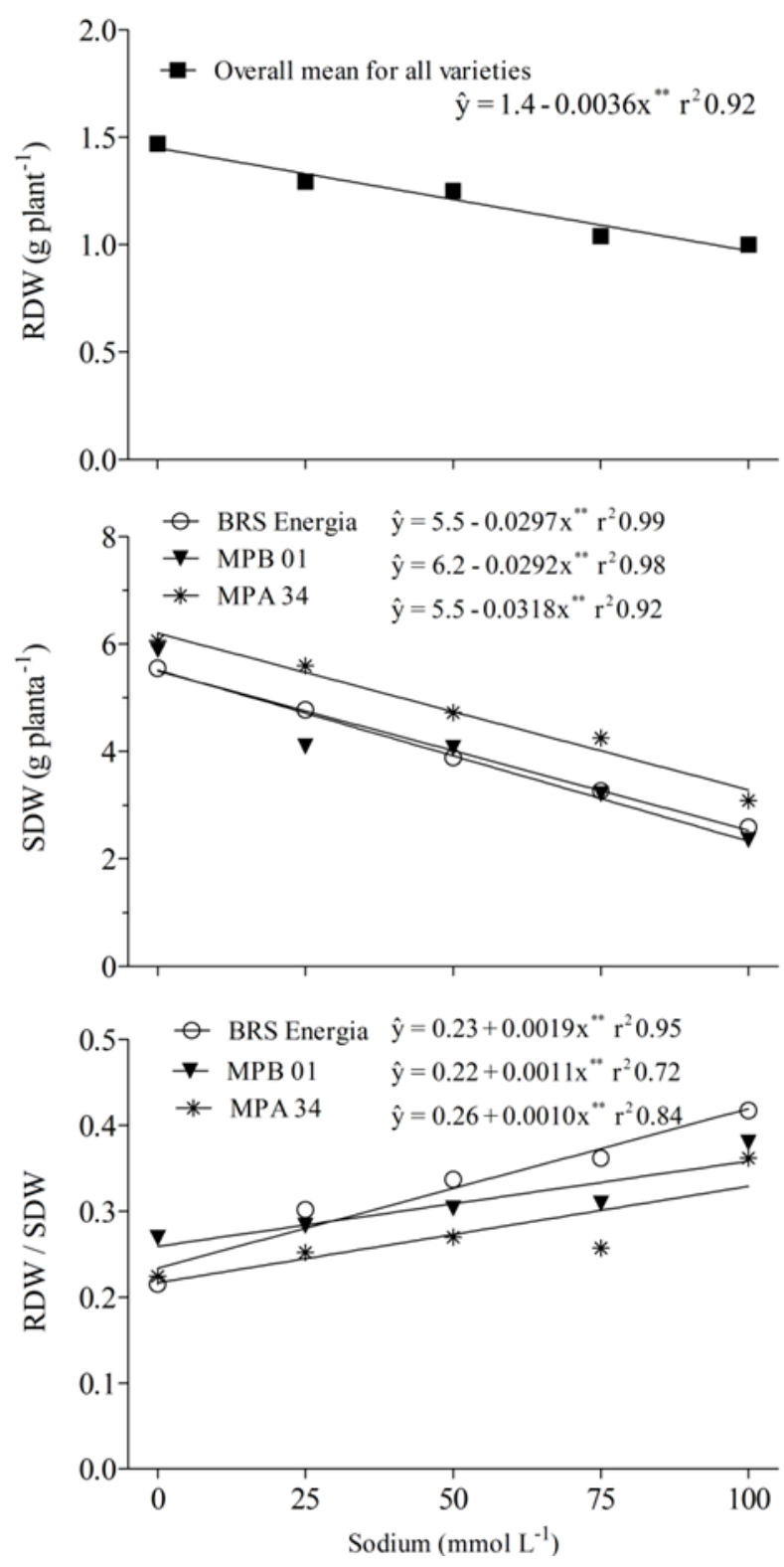

Figure 3. Root dry weight (RDW), shoot dry weight (SDW) and the RDW/SDW ratio for different castor bean varieties grown in nutrient solution with different salinity levels. ${ }^{*}{ }^{* *}$ : Coefficient significant at $\mathrm{p}<0.05$ or 0.01 , respectively. 
No significant differences in the percent shoot dry weight $(\% \mathrm{SDW})$ were observed among the different varieties. The \%SDW increased with the increasing salinity level in the nutrient solution (Figure 4).

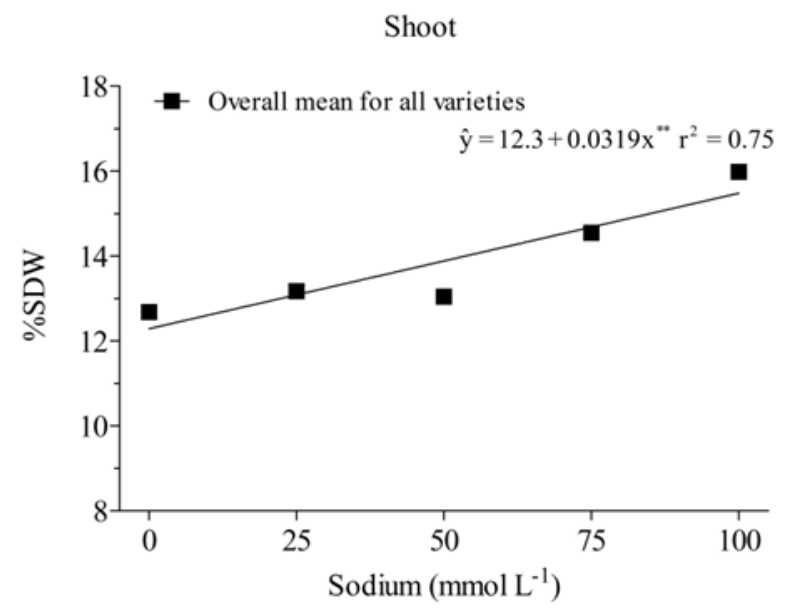

Figure 4. The percent shoot dry weight (\%SDW) of castor beans grown in nutrient solution with different salinity levels. Values are the overall means for all varieties. ${ }^{* *}$ : Coefficient significant at $\mathrm{p}<0.01$.

The \%SDW was negatively correlated with succulence, which is a term used in some drought and salinity studies. The \%RDW was not significantly affected and remained at approximately $5 \%$, probably because the plants were grown in nutrient solution. However, the \%SDW of the tested castor bean varieties increased from $12.7 \%$ (control treatment) to $16 \%$ with the highest sodium level, representing a $26 \%$ increase.

\section{CONCLUSION}

Salinity affected the early development of the tested castor bean varieties, with the shoot more affected than the root. Variety MPA 34 is promising for cultivation under moderate salinity level conditions.

\section{REFERENCES}

AL-KARAKI, G.; AL-AJMI, A.; OTHMAN, Y. Response of soilless grown bell pepper cultivars to salinity. Acta Horticulturae, East Lansing, v. 807, n. 1, p. $227-232,2009$

ARAGÃO, C. A. et al. Avaliação de cultivares de melão sob condições de estresse salino. Revista Caatinga, Mossoró, v. 22, n. 2, p. 161-169, 2009.

AYERS, R. S.; WESTCOT, D. W. A qualidade da água na agricultura. 2. ed. Campina Grande: UFPB, 1999. 218 p. (Estudos da FAO, Irrigação e Drenagem, 29).

BRAY, E. A.; BAILEY-SERRES, J.; WERETILNYK, E. Responses to abiotic stresses. In:
BUCHANAN, B. B.; GRUISSEM, W. JONES, R.L. (Eds.). Biochemistry \& Molecular Biology of Plants. American Society of Plant Physiologists, 2000. v. 1, cap. 22, p. 1158-1203.

CARUSO, G.; VILLARI, G. Effect of EC-level and plant shading on the NFT-grown "Friariello Pepper". Acta Horticulturae, East Lansing, v. 659, n. 2, p. 576-585, 2004.

CAVALCANTI, M. L. F. et al. Tolerância da mamoneira BRS 149 à salinidade: germinação e características de crescimento. Revista Brasileira de Engenharia Agrícola e Ambiental, Campina Grande, v. 9, Sup., p. 57-61, 2005.

CHEESEMAN, J. M. Mechanisms of salinity tolerance in plants. Plant Physiology, Rockville, v. 87, n. 1, p. $547-550,1988$.

CONAMA. Considerando ser a classificação das águas doces, salobras e salinas essencial à defesa de seus níveis de qualidade, avaliados por parâmetros e indicadores específicos, de modo a assegurar seus usos preponderantes. Diário Oficial da União, Brasília, 1986.

COSME, C. R. et al. Produção de tomate hidropônico utilizando rejeito da dessalinização na solução nutritiva aplicados em diferentes épocas. Revista Brasileira de Engenharia Agrícola e Ambiental, Campina Grande, v. 15, n. 5, p. 499-504, 2011.

HOAGLAND, D. R.; ARNON, D. I. The water culture method for growing plants without soil. Berkeley, Califórnia: College of Agriculture, University of California, 1950. 347 p. 
KLUGE, M; TING, I. P. Crassulace an Acid Metabolism: Analysis of an Ecological Adaptation. Springer - Verlag, Berlin, 1978.

KORNDÖRFER, G. H. Elementos benéficos In: FERNANDES, M. S. (Ed.). Nutrição mineral de plantas. Viçosa: Sociedade Brasileira de Ciência do Solo, 2006. v. 1, cap. 14, p. 355-374.

MAAS, E.V.; HOFFMAN, G.J. Crop salt tolerance-current assessment. Journal of Irrigation and Drainage Engineering, Delaware, v. 103, n. 6, p. $115134,1977$.

MARSCHNER, H. Mineral nutrition of higher plants. 2. ed. San Diego, USA: Academic Press, 1997. $889 \mathrm{p}$.

NUNES, R. L. C. et al. efeitos da salinidade da solução nutritiva na produção de pimentão cultivado em substrato de fibra de coco. Revista Caatinga, Mossoró, v. 26, n. 4, p. 48-53, 2013.

PINHEIRO, H. A. et al. Leaf gas exchange, chloroplastic pigments and dry matter accumulation in castor bean (Ricinus communis L.) seedlings subjected to salt stress conditions. Crop Production, Ithaca, v. 27, n. 1, p. 385-392, 2008.

RUBIO, J. S. et al. blossom-end rot incidence, and fruit quality in pepper plants under moderate salinity are affected by $\mathrm{K}^{+}$and $\mathrm{Ca}^{2+}$ fertilization. Scientia Horticulturae, Amsterdam, v. 119, n. 1, p. 79-87, 2009.

SANTOS, J. B. et al. Comportamento morfofisiológico da mamoneira BRS Energia submetida à irrigação com água salina. Revista Brasileira de Engenharia Agrícola e Ambiental, Campina Grande, v. 17, n. 2, p. 145-152, 2013.

SAS INSTITUTE INC. Statistical Analysis System user's guide. 1. ed. Cary, EUA, v. 9, 2002. 513 p.

SAVVAS, D. et al. Interactions between salinity and irrigation frequency in greenhouse pepper grown in closed-cycle hydroponic systems. Agricultural Water Management, Amsterdam, v. 91, n. 3, p. 102-111, 2007.

SILVA, J. K. M. et al. Efeito da salinidade e adubos orgânicos no desenvolvimento da rúcula. Revista Caatinga, Mossoró, v. 21, n. 5, p. 30-35, 2008a.

SILVA, S. M. S. et al. Desenvolvimento e produção de duas cultivares de mamoneira sob estresse salino. Revista Brasileira de Engenharia Agrícola e Ambiental, Campina Grande, v. 12, n. 4, p. 335-342, 2008b.
SILVA JÚNIOR, J. F. et al. Crescimento inicial de algodoeiro herbáceo submetido a estresse salino. Revista Caatinga, Mossoró, v. 1, n. 1, p. 42-47, 2013. 